\title{
A Holocene record of climate-driven shifts in coastal carbon sequestration
}

\author{
Siddhartha Mitra, ${ }^{1,2}$ Andrew R. Zimmerman, ${ }^{3}$ Glendon B. Hunsinger, ${ }^{2}$ Debra Willard, ${ }^{4}$ \\ and Joshua C. Dunn ${ }^{2}$ \\ Received 10 December 2008; revised 27 January 2009; accepted 5 February 2009; published 6 March 2009.
}

[1] A sediment core collected in the mesohaline portion of Chesapeake Bay was found to contain periods of increased delivery of refractory black carbon $(\mathrm{BC})$ and polycyclic aromatic hydrocarbons (PAHs). The $\mathrm{BC}$ was most likely produced by biomass combustion during four centennialscale dry periods as indicated by the Palmer Drought Severity Index (PDSI), beginning in the late Medieval Warm Period of 1100 CE. In contrast, wetter periods were associated with increased non-BC organic matter influx into the bay, likely due to greater runoff and associated nutrient delivery. In addition, an overall increase in both $\mathrm{BC}$ and non-BC organic matter deposition during the past millennium may reflect a shift in climate regime. The finding that carbon sequestration in the coastal zone responds to climate fluctuations at both centennial and millennial scales through fire occurrence and nutrient delivery has implications for past and future climate predictions. Drought-induced fires may lead, on longer timescales, to greater carbon sequestration and, therefore, represent a negative climate feedback. Citation: Mitra, S., A. R. Zimmerman, G. B. Hunsinger, D. Willard, and J. C. Dunn (2009), A Holocene record of climate-driven shifts in coastal carbon sequestration, Geophys. Res. Lett., 36, L05704, doi:10.1029/ 2008GL036875.

\section{Introduction}

[2] Widespread wildfires can play a significant role in global carbon cycling. Wildfires restructure the vegetative cover of a landscape, alter net ecosystem productivity, and result in elevated atmospheric greenhouse gas levels [Wiedinmyer and Neff, 2007]. However, because combustion of organic matter leads to formation of refractory carbon, wildfires may ultimately sequester carbon into soils and sediments. One approach to examining the historical relationship between fires, climate, and carbon sequestration is to compare proxies of paleoclimate with evidence of fires and organic matter storage in the geologic record. Typically, sedimentary records of fire history are reconstructed using charcoal abundance. Yet, inconsistencies in charcoal volume and density render it difficult to accurately extrapolate charcoal cross-sectional area to total pyrogenic carbon flux.

\footnotetext{
${ }^{1}$ Department of Geological Sciences, East Carolina University, Greenville, North Carolina, USA.

${ }^{2}$ Department of Geological Sciences and Environmental Studies, Binghamton University, Binghamton, New York, USA.

${ }^{3}$ Department of Geological Sciences, University of Florida, Gainsville, Florida, USA.

${ }^{4}$ U.S. Geological Survey, Reston, Virginia, USA.
}

Copyright 2009 by the American Geophysical Union. 0094-8276/09/2008GL036875
In contrast, black carbon (BC) is a highly condensed, refractory and polymerized residue of combustion [Hammes et al., 2007] ranging from char to smaller-sized soot aerosols $\sim 1 \mu \mathrm{m}$ in diameter [Palmer and Cullis, 1965] and is a more representative tracer than char for total pyrogenic carbon. Because of its slow microbial oxidation rates [Hamer et al., 2004], BC represents a pool of carbon that may be sequestered into the geosphere over geological timescales.

[3] In this study, chemically-isolated $\mathrm{BC}$ is used in conjunction with a suite of markers also resulting from combustion, polycyclic aromatic hydrocarbons (PAHs), to identify large-scale combustion events recorded in Chesapeake Bay sediment. Down-core analyses of BC, non-BC organic carbon (OC) and PAHs are compared to historical climate proxies in order to examine the influence of climate on carbon sequestration in the coastal zone. To our knowledge, these analyses provide the first quantitative record of pyrogenic carbon sequestration spanning the past two millennia and represent the only historical record of $\mathrm{BC}$ deposition in an estuarine environment. The Chesapeake Bay estuary was chosen as an ideal location for this study because it captures the runoff from a geographically large area that is climatically-sensitive, and contains lengthy records of pollen, microfossils, biogeochemical changes, and environmental variability [e.g., Cooper and Brush, 1993; Cronin et al., 2000; Colman and Bratton, 2003].

\section{Methods}

[4] The sediment cores studied were collected just east of the Potomac River confluence $\left(38^{\circ} 1.822^{\prime} \mathrm{N}, 76^{\circ} 12.876^{\prime}\right.$ $\mathrm{W} ; 26.1 \mathrm{~m}$ water depth). This site has been shown by other studies [e.g., Cronin et al., 2003; Cronin and Vann, 2003; Willard et al., 2003] to store sediments reflective of regional watershed processes. Mass accumulation rates were determined using ${ }^{210} \mathrm{~Pb}$, bivalve ${ }^{14} \mathrm{C}$, and pollen analyses (auxiliary material) ${ }^{1}$. A HF acid demineralization followed by dichromate-sulfuric acid oxidation procedure was used to isolate $\mathrm{BC}$ ranging from char to soot [Hammes et al., 2007]. Chemo-thermal oxidation was used to isolate just the soot portion of BC for a few samples [Elmquist et al., 2004]. Sediments were analyzed for PAHs using organic solvent extraction [Hunsinger et al., 2008]. Additional methodological details may be found in the auxiliary material.

\section{Results and Discussion}

[5] The sediment core studied contains a depositional record spanning the past $4 \mathrm{ka}$. Concentrations of $\mathrm{BC}$ and

\footnotetext{
${ }^{1}$ Auxiliary materials are available in the HTML. doi:10.1029/ 2008GL036875.
} 


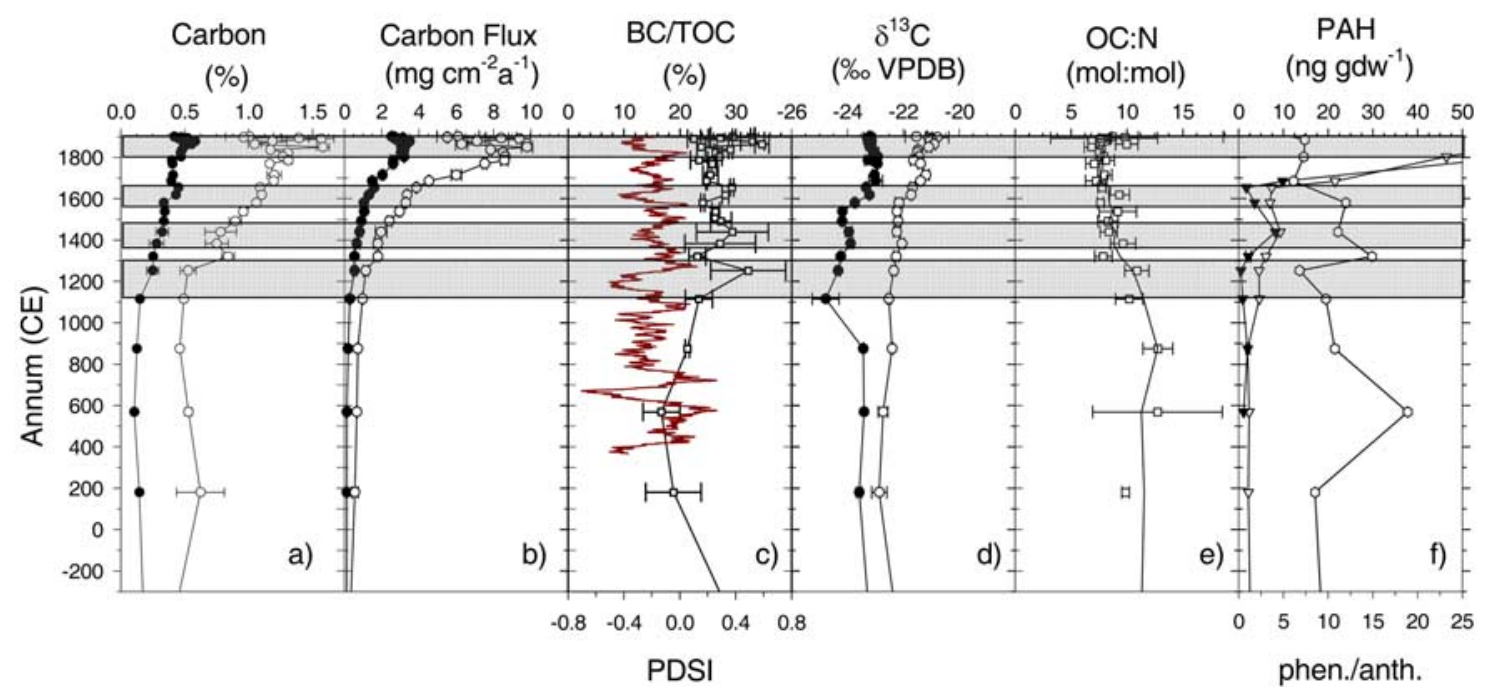

Figure 1. Chesapeake Bay core profiles of (a) concentrations of black carbon (BC: solid circles), and non-BC organic carbon (OC: open circles), (b) depositional fluxes of $\mathrm{BC}$ and $\mathrm{OC}$ (filled and open circles, respectively), (c) fraction of $\mathrm{BC}$ relative to total organic carbon (BC/TOC\%: open squares) and historical Palmer Drought Severity Index (PDSI) from southeastern North Carolina, U.S. (line plot) [Stahle et al., 1988], (d) carbon stable isotopic signatures of BC and OC (filled and open circles, respectively), (e) atomic OC to total nitrogen ratio, and (f) the polycyclic aromatic hydrocarbon compounds pyrene (open triangles) and benzo(a)pyrene (closed triangles), and the ratio of the isomers, phenanthrene:anthracene (open circles). All error bars depict the standard deviation about the mean result of duplicate analyses. The data for $-3000 \mathrm{CE}$ to $-200 \mathrm{CE}$ are not displayed due to the constant and low values occurring during this period.

OC and their rates of delivery are low and constant throughout the lower portion of the core (Figures 1a and 1b). After $1000 \mathrm{CE}$, there is a clear and sustained increase in both $\mathrm{OC}$ and $\mathrm{BC}$. The proportion of total organic carbon (TOC) that is $\mathrm{BC}$ increases from an average of $16 \pm 4 \%$ in lower core sediments to $36 \pm 6 \%$ in the upper core (1000 to $1830 \mathrm{CE}$; Figure 1c). Thus, BC represents a major portion of the TOC in these coastal sediments, comparable to that found in some other systems including soils, and river and marine sediments [e.g., Song et al., 2002; Masiello and Druffel, 2003]. Only pre-industrial age sediments (pre-1830 [Lima et al., 2003]) are examined here so as to avoid the influence of fossil fuel combustion-derived BC.

\subsection{Sources of Organic Carbon to Chesapeake Bay}

[6] Carbon stable isotopic signatures provide information on the sources of OC and $\mathrm{BC}$ deposited at this site (Figure 1d). The stable isotopic signature of $\mathrm{OC}\left(\delta^{13} \mathrm{C}_{\mathrm{OC}}\right)$ measured in the core, -20.6 to $-22.7 \%$ (VPDB), indicate either a mixture of biogenic $\mathrm{OC}$ sources that could include terrestrial $\mathrm{C} 3$ plants $\left(\delta^{13} \mathrm{C}\right.$ of -30 to $\left.-27 \%\right)$, terrestrial $\mathrm{C} 4$ plant or salt marsh and seagrass vegetation $\left(\delta^{13} \mathrm{C}\right.$ of -7 to $-13 \%$ ), or autochthonous sources of organic matter including aquatic algae and bacteria $\left(\delta^{13} \mathrm{C}\right.$ of -18 to -22$)$ [Collister et al., 1994]; Molar OC:N ratios of 8 to 12 (Figure 1e) suggest a predominance of the latter at this site.

[7] Possible sources of material identified as $\mathrm{BC}$ to Chesapeake Bay sediments include petrogenic carbon, derived from the weathering of kerogen-containing rocks in the watershed, refractory geopolymers from plant-derived soil organic matter, or pyrogenic carbon derived from combusted biomass either within the bay's watershed (charcoal) or airshed (soot). Although petrogenic material has been found to represent a significant portion of the refractory carbon exported to some coastal systems [Raymond and Bauer, 2001], the only significant sources of petrogenic carbon in the watershed, Devonian black shales of the Appalachian Province and the Paleozoic coals of central Pennsylvania, are found in less than $10 \%$ of the watershed area. Moreover, these shales have consistently depleted $\delta^{13} \mathrm{C}_{\mathrm{OC}}$ signatures $(-30$ to $-32 \%)$ [Werne et al., 2002], quite different from the $\delta^{13} \mathrm{C}_{\mathrm{BC}}$ of -23 to $-25 \%$ in the studied core. Refractory soil-derived geopolymers, as well as acid-resistant paraffinic structures that may protect uncharred and even labile plant organic matter, may not be adequately removed by HF demineralization and $\mathrm{Cr}_{2} \mathrm{O}_{7}=$ oxidation [Knicker, 2007]. Therefore, $\mathrm{BC}$ isolation methods such as the $\mathrm{Cr}_{2} \mathrm{O}_{7}=$ technique used in this study cannot distinguish between refractory organic matter originating from pedogenesis and that of petrogenic or pyrogenic BC.

[8] While petrogenic or pedogenic geopolymers may contribute to sedimentary BC, the distribution of polycyclic aromatic hydrocarbons (PAH) in these sediments suggests a pyrogenic origin. First, downcore concentration profiles of the pyrogenic PAHs, pyrene and benzo[a]pyrene (Figure 1f), are similar to that of $\mathrm{BC}$. Also, the sedimentary ratios of phenanthrene plus anthracene to their alkylated homologs, $2.5 \pm 0.9$ (Table S2), are indicative of a pyrogenic origin [Yunker et al., 2002]. Lastly, pyrogenic $\mathrm{BC}$ has been shown to reflect the isotopic signature of its parent combusted biomass [Czimczik et al., 2002; Turney et al., 2006], although isotopic depletions of up to $5 \%$ have been observed for some $\mathrm{C} 4$ grasses [Krull et al., 2003]. Because $\delta^{13} \mathrm{C}_{\mathrm{BC}}$ is negatively offset from $\delta^{13} \mathrm{C}_{\mathrm{OC}}$ by as much as $4 \%$, and because the two signatures vary dissimilarly downcore, 
$\mathrm{OC}$ and $\mathrm{BC}$ are likely from distinct biomass sources. The carbon isotopic signature of $\mathrm{BC}$ indicates a combusted parent biomass of mainly $\mathrm{C} 3$ plants with temporally variable admixtures of material from $\mathrm{C} 4$ plants such as grasses, or humified $\mathrm{C} 4$ plant remains.

[9] Possible routes of entry for $\mathrm{BC}$ to estuarine sediment include local shoreline erosion, fluvial transport, and aeolian deposition. A large portion of the $\mathrm{BC}$ in the core is determined to be soot (46\% and $77 \%$ in 110 and $287 \mathrm{~cm}$ core depth sediments, respectively). In addition, the high phenanthrene:anthracene PAH ratio found in the sediments (substantially $>1$ and variable; Figure 1f) are indicative of a high degree of photodegradation [Dickhut et al., 2000], likely due to mixing of materials with both long and short atmospheric transport times [Behymer and Hites, 1988]. Together, these data indicate that fires located over a large area of the Chesapeake Bay airshed are the main sources of $\mathrm{BC}$ to these sediments.

\subsection{Climate and Carbon Deposition in the Chesapeake Bay}

[10] Although the downcore decrease in $\mathrm{OC}$ and $\mathrm{BC}$ concentration and flux might be explained by organic compound decomposition (diagenesis), this mechanism is unlikely because: 1) the downcore decrease in concentration is not exponential as would be expected of a diagenetic profile [Berner, 1980], 2) profiles of labile and refractory organic components ( $\mathrm{OC}$ and $\mathrm{BC}$ abundance, respectively) are similar, and 3) changes in carbon isotopic signatures of BC and OC, which should be unchanged [Meyers, 1994] or become enriched with diagenesis [Freudenthal et al., 2001], are synchronous with changes in $\mathrm{BC}$ and $\mathrm{OC}$ quantity. Instead, chemical signatures indicate that temporal variations in the quantity and source of organic matter delivered to the site have occurred.

[11] Multi-decadal to centennial-scale oscillations in the delivery of $\mathrm{BC}$ and $\mathrm{OC}$ components to the sediment are most clearly seen in the $\mathrm{BC} / \mathrm{TOC}$ ratio profile through the upper portion of the core (Figure 1c). Oscillations of these types may have occurred prior to this time, but they are not evident in the data given the low temporal resolution of the lower portion of the core (samples integrate up to 400 years of deposition). After $1100 \mathrm{CE}$, there are four time periods, indicated by shaded horizontal bars in Figure 1, during which $\mathrm{BC}$ concentration and delivery increase dramatically relative to TOC. Though sampling at higher resolution is clearly necessary to better define these periods of enhanced $\mathrm{BC}$ delivery, at present, each of these periods seem to be correlated to climatically dry periods in the mid-Atlantic region, as indicated by extended low values of the Palmer Drought Severity Index (PDSI: Figure 1c) [Stahle et al., 1988]. This drought index, based on tree-ring data, integrates historical climatic factors such as soil moisture, precipitation, and temperature. The first major compositional shift occurs during 1100-1300 CE, a time referred to as the Medieval Warm Period (MWP). Evidence for local warming and drought during the MWP has been found in records of Chesapeake Bay sediment chemistry, pollen [Willard et al., 2003], and ostracode tests $(\mathrm{Mg} / \mathrm{Ca}$ ratios [Cronin et al., 2003]). In addition, Brush [1986] has noted increased charcoal deposition in Chesapeake Bay sediments from other locations at the onset of the MWP.
[12] The increase in BC arriving in Chesapeake Bay sediments during relatively arid intervals must be the result of more spatially extensive, intensive or frequent burning events and/or greater export of $\mathrm{BC}$ during these periods. After an initial decrease at the start of the MWP, an increase in $\delta^{13} C_{\mathrm{BC}}$ values is associated with four of the five dry intervals (Figure 1c). The initial decrease can be explained by a sudden increase in pyrogenic relative to non-pyrogenic $\mathrm{BC}$, while later isotopic enrichments can be attributed to increases in the relative proportion of $\mathrm{C} 4$ versus $\mathrm{C} 3$ vegetation in the combusted biomass. The increased proportion of $\mathrm{C} 4$ grasses may be explained by their relative competitive advantage during arid climatic periods [Schulze et al., 1996], or to their tendency to colonize frequently burned areas [Biggs et al., 2002]. In contrast, relatively wetter periods (with more positive PDSI values) are associated with increased OC deposition and, in some cases, decreased $\mathrm{OC}: \mathrm{N}$ and negative $\delta^{13} \mathrm{C}_{\mathrm{OC}}$ excursions. This is consistent with higher levels of autochthonous production, which may have resulted from relatively greater riverine inflows that would have delivered more nutrients to Chesapeake Bay during wetter periods.

[13] The 18th and 19th century increases in OC and BC delivery can certainly be attributed to widespread agricultural land clearance with European settlement beginning at $\sim 1700 \mathrm{CE}$ and the production of charcoal for iron smelting at $\sim 1800 \mathrm{CE}$, respectively. It is tempting to attribute the overall increase in both $\mathrm{BC}$ and $\mathrm{OC}$ delivery throughout the past millennia to the increasing human influence in the region during that period as well. Maize-farming villages, intensified agriculture, and accelerated population growth in eastern North America are thought to have begun in the early part of the millennium [Fritz, 1995]. However, evidence for extensive agricultural land clearance and hunting-related burning by aboriginals is equivocal [Russell, 1983]. Furthermore, it is difficult to imagine that the small number of indigenous hunter-gatherers of $1100 \mathrm{CE}$ could have produced the striking changes in carbon cycling observed without climate having been a major contributing factor.

[14] An increase in the degree of decadal- to centennialscale climate variability during the past millennia may have led to enhanced delivery of both $\mathrm{OC}$ and $\mathrm{BC}$ to Chesapeake Bay. Wetter periods would have produced more fuel for subsequent burning during droughts, and dryer periods of greater fire frequency or intensity would have resulted in soil erosion leading to increased nutrient delivery to coastal zones during ensuing wet periods. Evidence for relatively higher amplitude climate variations during the past millennium has been found in pollen, microfossil and sediment chemistry records of the Chesapeake Bay [Cronin et al., 2003; Willard et al., 2003] and the Atlantic Ocean. These have been attributed to long-term shifts in the strength of North Atlantic thermohaline circulation [Keigwin, 1996; Bond et al., 1997] or oscillations in major atmospheric circulation cells [Vega et al., 1998].

[15] Because of its geographical position relative to the jet stream and proximity to the North Atlantic, the Chesapeake Bay watershed is expected to be sensitive to globalscale climatic oscillations [Najjar et al., 2009]. For example, though much different in resolution, a correspondence exists between the relative abundance of sedimentary BC in 


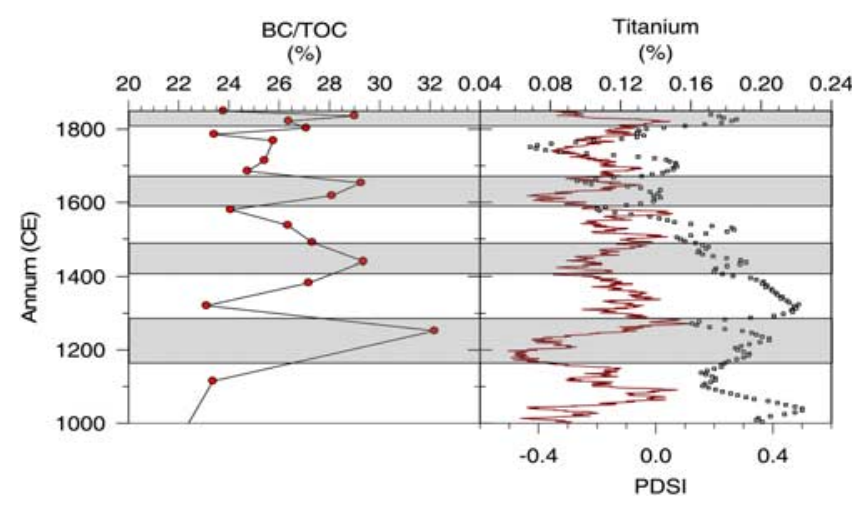

Figure 2. Fraction of BC/TOC (filled circles) in Chesapeake Bay compared to 5 year moving average of the Cariaco Basin sediment titanium record (open squares) [Haug et al., 2001] and historical Palmer Drought Severity Index (PDSI) from southeastern North Carolina, U.S. (line plot) [Stahle et al., 1988]. Shaded areas highlight enrichments in Chesapeake Bay $\mathrm{BC} / \mathrm{TOC}$ that correspond with negative excursions in PDSI (Middle Atlantic U.S.: dry) and positive excursions in Cariaco Basin titanium (S. America tropical: wet).

the Chesapeake Bay core and titanium abundance in Cariaco Basin sediment (Figure 2). These titanium influxes have been attributed to increased tropical precipitation in northern South America and are linked to northward migrations of the Inter-Tropical Convergence Zone (ITCZ) [Haug et al., 2001], which are, in turn, related both to stronger Atlantic Ocean temperature gradients and El Nino Southern Oscillation (ENSO) events. Northward migrations in the ITCZ may signal enhanced meridional flow patterns which are known to produce dryness in the eastern U.S. [HendersonSellers and Robinson, 1986]. Such hemisphere-scale climatic phenomena may have resulted in greater wildfire occurrence in the Chesapeake Bay airshed and resulted in increased BC deposition in the coastal zone.

[16] While others have noted associations between drought periods and increased charcoal in local sediment records [Bird and Cali, 1998; Pederson et al., 2005], these findings document the first evidence of climate-controlled centennial- and millennial-scale oscillations in the sequestration of both $\mathrm{BC}$ and $\mathrm{OC}$ in the coastal zone. They suggest that, while the increased incidence of wildfires that may occur with climate change could release additional $\mathrm{CO}_{2}$ to the atmosphere [Wiedinmyer and Neff, 2007], this could be countered over the long term by increased soil or sediment sequestration of $\mathrm{BC}$, a refractory material not quickly degraded, chemically [Masiello, 2004] or microbially [Hamer et al., 2004]. This sink for atmospheric $\mathrm{CO}_{2}(\mathrm{~g})$ into an estuarine environment would represent a negative climate feedback and may play a regulatory role in centennial and millennial-scale climate variability. Sampling at both finer time and greater spatial-scales is needed to quantify the magnitude and effects of this coastal zone carbon sink.

[17] Acknowledgments. This research was supported by ACS-PRF and the Binghamton University Research Foundation. Sediments and some chronometric information were provided by Antonio Mannino (NASA) and funding for vessel time provided by the U.S. Geological Survey.

\section{References}

Behymer, T. D., and R. A. Hites (1988), Photolysis of polycyclic aromatic hydrocarbons adsorbed on fly ash, Environ. Sci. Technol., 22, $1311-1319$.

Berner, R. (1980), Early Diagenesis: A Theoretical Approach, 241 pp., Princeton Univ. Press, Princeton, N. J.

Biggs, T. H., et al. (2002), Delta C-13 values of soil organic matter in semiarid grassland with mesquite (Prosopis) encroachment in southeastern Arizona, Geoderma, 110, 109-130.

Bird, M. I., and J. A. Cali (1998), A million-year record of fire in subSaharan Africa, Nature, 394, 767-769.

Bond, G., et al. (1997), A pervasive millennial-scale cycle in North Atlantic Holocene and glacial climates, Science, 278, 1257-1266.

Brush, G. S. (1986), Geology and paleoecology of Chesapeake Bay: A longterm monitoring tool for management, J. Wash. Acad. Sci., 76, $146-160$.

Collister, J. W., et al. (1994), Compound-specific $\delta^{13} \mathrm{C}$ analyses of leaf lipids from plants with differing carbon-dioxide metabolisms, Org. Geochem., 21, 619-627.

Colman, S. M., and J. F. Bratton (2003), Anthropogenically induced changes in sediment and biogenic silica fluxes in Chesapeake Bay, Geology, 31, 71-74.

Cooper, S. R., and G. S. Brush (1993), A 2,500-year history of anoxia and eutrophication in Chesapeake Bay, Estuaries, 16, 617-626.

Cronin, T. M., and C. D. Vann (2003), The sedimentary record of climatic and anthropogenic influence on the Patuxent estuary and Chesapeake Bay ecosystems, Estuaries, 26, 196-209.

Cronin, T. M., et al. (2000), Climatic variability in the eastern United States over the past millennium from Chesapeake Bay sediments, Geology, 28, $3-6$.

Cronin, T. M., et al. (2003), Medieval Warm Period, Little Ice Age, and 20 th century temperature variability from Chesapeake Bay, Global Planet. Change, 36, 17-29.

Czimczik, C. I., et al. (2002), Effects of charring on mass, organic carbon, and stable carbon isotopic composition of wood, Org. Geochem., 33, $1207-1223$

Dickhut, R. M., et al. (2000), Automotive sources of carcinogenic polycyclic aromatic hydrocarbons associated with particulate matter in the Chesapeake Bay region, Environ. Sci. Technol., 34, 4635-4640.

Elmquist, M., et al. (2004), Quantification of sedimentary black carbon using the chemothermal oxidation method: An evaluation of ex situ pretreatments and standard addition approaches, Limnol. Oceanogr. Methods, 2, 417-427.

Freudenthal, T., et al. (2001), Early diagenesis of organic matter from sediments of the eastern subtropical Atlantic: Evidence from stable nitrogen and carbon isotopes, Geochim. Cosmochim. Acta, 65, $1795-1808$

Fritz, G. J. (1995), New dates and data on early agriculture - the legacy of complex hunter-gatherers, Ann. Mo. Bot. Garden, 82, 3-15.

Hamer, U., et al. (2004), Interactive priming of black carbon and glucose mineralization, Org. Geochem., 35, 823-830.

Hammes, K., et al. (2007), Comparison of quantification methods to measure fire-derived (black/elemental) carbon in soils and sediments using reference materials from soil, water, sediment and the atmosphere, Global Biogeochem. Cycles, 21, GB3016, doi:10.1029/2006GB002914.

Haug, G. H., et al. (2001), Southward migration of the Intertropical Convergence Zone through the Holocene, Science, 293, 1304-1308.

Henderson-Sellers, A., and P. J. Robinson (1986), Contemporary Climatology, Longman, London.

Hunsinger, G. B., S. Mitra, J. A. Warrick, and C. R. Alexander (2008), Oceanic loading of wildfire-derived organic compounds from a small mountainous river, J. Geophys. Res., 113, G02007, doi:10.1029/ 2007JG000476.

Keigwin, L. D. (1996), The Little Ice Age and Medieval warm period in the Sargasso Sea, Science, 274, 1504-1508.

Knicker, H. (2007), How does fire affect the nature and stability of soil organic nitrogen and carbon? A review, Biogeochemistry, 85, 91-118.

Krull, E. S., et al. (2003), ${ }^{13}$ C-depleted charcoal from C4 grasses and the role of occluded carbon in phytoliths, Org. Geochem., 34, $1337-1352$.

Lima, A. L., et al. (2003), High-resolution record of pyrogenic polycyclic aromatic hydrocarbon deposition during the 20th Century, Environ. Sci. Technol., 37, 53-61.

Masiello, C. A. (2004), New directions in black carbon organic geochemistry, Mar. Chem., 92, 201-213.

Masiello, C. A., and E. R. M. Druffel (2003), Organic and black carbon $13 \mathrm{C}$ and $14 \mathrm{C}$ through the Santa Monica Basin sediment oxic-anoxic transition, Geophys. Res. Lett., 30(4), 1185, doi:10.1029/2002GL015050.

Meyers, P. (1994), Preservation of elemental and isotopic source identification of sedimentary organic matter, Chem. Geol., 114, 289-302. 
Najjar, R., et al. (2009), Climate simulations of major estuarine watersheds in the Mid-Atlantic region of the US, Clim. Change, doi:10.1007/s10584$10008-19521-y$, in press.

Palmer, H. B., and C. F. Cullis (1965), The formation of carbon from gases, in Chemistry and Physics of Carbon-A Series of Advances, edited by P. L. Walker Jr. et al., pp. 266-319, Marcel Dekker, New York.

Pederson, D. C., et al. (2005), Medieval warming, Little Ice Age, and European impact on the environment during the last millennium in the lower Hudson Valley, New York, USA, Quat. Res., 63, 238-249.

Raymond, P. A., and J. E. Bauer (2001), Riverine export of aged terrestrial organic matter to the North Atlantic Ocean, Nature, 409, 497-500.

Russell, E. W. B. (1983), Indian-set fires in the forest of the northeastern United States, Ecology, 64, 78-88.

Schulze, E. D., et al. (1996), Diversity, metabolic types and $\delta^{13} \mathrm{C}$ carbon isotope ratios in the grass flora of Namibia in relation to growth form, precipitation and habitat conditions, Oecologia, 106, 352-369.

Song, J., et al. (2002), Black carbon and kerogen in soils and sediments. 1. Quantification and characterization, Environ. Sci. Technol., 36, $3960-3967$.

Stahle, D. W., et al. (1988), North Carolina climate changes reconstructed from tree rings-AD 372 to 1985, Science, 240, 1517-1519.

Turney, C. S. M., et al. (2006), Carbon isotope fractionation in wood during carbonization, Geochim. Cosmochim. Acta, 70, 960-964.
Vega, A. J., et al. (1998), Interannual to interdecadal variations of the regionalized surface climate of the United States and relationships to generalized flow parameters, Phys. Geogr., 19, 271-291.

Werne, J. P., et al. (2002), An integrated assessment of a "type euxinic" deposit: Evidence for multiple controls on black shale deposition in the Middle Devonian Oatka Creek Formation, Am. J. Sci., 302, 110-143.

Wiedinmyer, C., and J. C. Neff (2007), Estimates of $\mathrm{CO}_{2}$ from fires in the United States: Implications for carbon management, Carbon Balance Manage., 2, 10, doi:10.1186/1750-0680-2-10.

Willard, D. A., et al. (2003), Late-Holocene climate and ecosystem history from Chesapeake Bay sediment cores, Holocene, 13, 201-214.

Yunker, M. B., et al. (2002), PAHs in the Fraser River Basin: A critical appraisal of PAH ratios as indicators of PAH source and composition, Org. Geochem., 33, 489-515.

J. C. Dunn and G. B. Hunsinger, Department of Geological Sciences and Environmental Studies, Binghamton University, P.O. Box 6000, Binghamton, NY 13902-6000, USA.

S. Mitra, Department of Geological Sciences, East Carolina University, 101 Graham Building, Greenville, NC 27858, USA. (mitras@ecu.edu)

D. Willard, U.S. Geological Survey, 926a National Center, 1220 Sunrise Valley Parkway, Reston, VA 20192, USA.

A. R. Zimmerman, Department of Geological Sciences, University of Florida, 241 Williamson Hall, Gainsville, FL 32611, USA. 